\title{
Potential Harmful Effects of Carbamazepine on Aquatic Organisms, A Study Using Ants as Invertebrate Models
}

\author{
Marie-Claire Cammaerts ${ }^{1}$, David Cammaerts ${ }^{2} \&$ Zoheir Rachidi $^{1}$ \\ ${ }^{1}$ Faculté des Sciences, Université Libre de Bruxelles, Bruxelles, Belgium \\ ${ }^{2}$ Independant Researcher (chercheur invité, ULB) \\ Correspondence: Marie-Claire Cammaerts, DBO, CP 160/12, Université Libre de Bruxelles, 50, Av. F.D. \\ Roosevelt, 1050 Bruxelles, Belgium. E-mail: mtricot@ulb.ac.be
}

Received: April 17, 2015 Accepted: May 20, 2015 Online Published: May 25, 2015

doi:10.5539/ijb.v7n3p75 URL: http://dx.doi.org/10.5539/ijb.v7n3p75

\begin{abstract}
One of the most common pharmaceutical substances present in natural water is carbamazepine, a drug given to persons suffering from epilepsies or pain in their cerebral nervous system, and eliminated intact by the kidneys through sewage systems into rivers. This substance may affect macroinvertebrates and vertebrates depending on watercourses. We thus studied its physiological and ethological effects on ants used as biological models. Carbamazepine decreased the ants' speed of locomotion, increasing so their sinuosity of movement. It decreased the precision of their reaction, their 'audacity', their research activity for food, their cognitive ability in navigating through chicanes, and slightly reduced their olfactory perception. It did not impact their response to pheromones, their brood caring behavior, and their visual perception. It somewhat reduced their tactile perception, induced aggressiveness between congeners while slightly reducing that towards aliens. Carbamazepine largely increased the ants' ability in acquiring visual and olfactory conditioning, as well as their visual and olfactory memory. Ants never developed dependence on, or habituation to, that drug consumption. After its consumption ended, the effects of carbamazepine vanished in $20 \mathrm{hrs}$ (for the linear speed), $26 \mathrm{hrs}$ (for the sinuosity), and $32 \mathrm{hrs}$ (for the orientation towards an alarm signal). These different physiological and ethological effects, revealed on ants, may occur for persons consuming that drug, and for living organisms depending on natural water contaminated by that drug. Attention should so be paid, as for these effects, to persons cared of with carbamazepine, and improved systems of depuration should be set up for eliminating that drug (as well as several other pharmaceutical pollutant substances) from the (yet not sufficiently) treated waste waters.
\end{abstract}

Keywords: aggressiveness, cognition, conditioning, locomotion, memory, tactile perception

\section{Introduction}

Pollution of watercourses by human artificially produced pharmaceutics, e.g. drugs, is now widespread (Lecomte, 2014; Petrovic et al, 2013). These substances are released intact or nearly intact into wastewater because they are poorly degraded by human's physiological systems. They are diverse in their chemical nature and are liberated in natural watercourses in very small amounts (ranging from 10 to 100 nanograms per liter, Lecomte, 2014) when wastewaters are not, or inefficiently, treated. Indeed, these substances are usually not degraded by bacteria in the water treatment plants because of their artificial nature, being synthesized in laboratories. Their impacts on biota are poorly known so far. They can have harmful impacts on the biology of aquatic animals, being invertebrates or vertebrates (Ramirez-Castillo, 2014; Corcoran, Winter, \& Tyler, 2010; Rosi-Marshall \& Royer, 2012; Arnold et al., 2013). Hormonal derivates chemicals may disrupt endocrinal processes and cause changes is sex-ratio, affect sexual and reproductive behavior, or cause impairment of development resulting in physical malformations in populations of aquatic invertebrates (Sutcliffe, 1994; Olsson, Borg, Brunström, Häkansson, \& Klasson-Wehler, 1998; Rilovl, Gasith, Evans, \& Benayahu, 2000; Preston, 2002; Knoery, 2010). Antibiotics may cause dramatic changes in bacterial populations of water bodies, with specific growth of species that are resistant to antibiotics (Ash \& Iverson, 202; Young, 1993; Kolpin et al., 2002; Kümmerer, 2009). Antidepressants (the most common one in natural water bodies being fluoxetine) may cause modification in social and group behaviors of fishes, leading to reduced prey captures abilities and even aggressiveness between congeners (Brodin, Fick, Jonsson, \& Klaminder, 2013; Sauvé, 2011; Klaper, 2013). So, a vast majority of human produced substances - i.e. drugs, but also other ones (Arzul, Quiniou, Croquette, \& Caisey, 2002) - released in natural water are presumed to have some 
potential harmful effects but, for most of them, these effects remain unknown or poorly studied. (Petrovic et al., 2013). One of these pharmaceutical substances, carbamazepine, is very common in watercourses, at variable concentrations (Website 'risques environnementaux'). This substance is used for treatment of persons suffering from epilepsies and inflammation of cerebral nervous system (nervous V, VII, and IX) and some of its adverse effects on humans are known (Carbamazépine, 2015; Guide des médicaments, 2015; Carbamazepine, 2015). But, probably, not all the effects have been studied. Moreover, until now, nothing or nearly nothing is known about the potential harmful effects of carbamazepine on aquatic organisms. As far as we know, no study has been made on these potential effects on macro-invertebrates living in natural water (Ginebreda, Munoz, Lopez de Alda, Brix, Lopez-Doval \& Barcelo, 2009; Damásio et al., 2011). These last organisms play important roles in the ecology of water bodies (Giller \& Malmqvist, 2002; Brönmark \& Hanson, 2002; Dodds, 2002; Tachet et al., 2010), occupying a variety of ecological niches and performing a huge variety of behaviors, so that any modifications of these behaviors could lead to significant changes in the trophic relationship between organisms of the aquatic fauna. It is thus important to know the potential effects of carbamazepine on these invertebrates to prevent dramatic changes in the behavioral, trophic and developmental processes occurring in aquatic ecosystems.

It is somewhat difficult to study ethological and physiological traits of macro-invertebrates. To do so in laboratories, sophisticated experimental material is required, and moreover, it is not easy to artificially maintain these animals alive during long time periods for ethological experiments without expensive water supply system and water filtration systems. So, it could be useful to have an "easy to maintain - easy to study" biological model (for invertebrate organisms, among others) for developing such kind of studies.

Indeed, since most of the biological processes are quite similar for all animals, including humans (i.e. genetics, metabolism, nervous cells functioning), a lot of invertebrates and vertebrates can be used as models for studying biological questions (Kolb \& Whishaw, 2002; Wehner \& Gehring, 1999; Russell \& Burch, 2014). Invertebrates are more and more used as biological models because they offer scientists many advantages, among others a short life cycle, a simple anatomy, and being available in large numbers (Wolf \& Heberlein, 2003; Søvik \& Barron, 2013). Some species are largely used as biological models, for instance, the flatworm Dendrocelium lacteum, the nematode worm Caenorhabdotes elegans, the mollusk Aplysia californica, the beetle Tribolim castaneum, the fruit fly Drosophila melanogaster, and the domestic bee Apis mellifera. Among the invertebrates, insects, especially social hymenoptera and among them, bees, are advantageously used as biological models (Andre, Wirtz, \& Das, 2008; Abramson, Wells, \& Janko, 2007).

Ants also could be used. Colonies containing thousands of ants can easily be maintained in laboratories, at low cost and very conveniently, throughout the entire year. Ants are among the most complex and social invertebrate animals as for their morphology, their physiology, their social organization and their behaviors. They are among the most morphologically evolved hymenoptera, having indeed a unique resting position of their labium, mandibles and maxilla (Keller, 2011), as well as a lot of glands emitting numerous, efficient pheromones (Billen \& Morgan, 1998). Their societies are highly organized with a strong division of labor, an age-based polyethism and a social regulation (Hölldobler \& Wilson, 1990). Their behavior is well developed: they care for their brood, build sophisticated nests, chemically mark the inside of their nest, and, differently, their nest entrances, their nest surroundings and their foraging area (Passera \& Aron, 2005). They generally use an alarm signal, a trail pheromone, and a recruitment signal (Passera \& Aron, 2005); they are able to navigate using memorized visual and olfactory cues (Cammaerts, 2012 and references therein); they efficiently recruit nestmates where, when and as long as it is necessary (Passera, 2006), and, finally, they clean their nest and provide their area with cemeteries (Keller \& Gordon, 2006). So, according to the complexity of their society and their behavior, it looks reasonable to use ants as biological models for studying physiological and ethological effects of neuronal active substances.

During many years, we have studied the ant's species belonging to the genus Myrmica, and above all Myrmica sabuleti Meinert 1861. We know some of its ecological traits, eye morphology, visual perception, navigation system, visual and olfactory conditioning capabilities, and recruitment strategy (Rachidi, Cammaerts, \& Debeir, 2008; Cammaerts, 2008; Cammaerts \& Rachidi, 2009; Cammaerts, Rachidi, \& Cammaerts, 2011). The ontogenesis of cognitive abilities of Myrmica species, including M. sabuleti, has also been approached (Cammaerts \& Gosset, 2014; Cammaerts, 2013a, 2013b, 2014a, 2014b). Studies on the impact of age, activity and diet on M. ruginodis' conditioning capability (Cammaerts \& Gosset, 2014) leaded to presume that ants could be good biological models. This was confirmed by the study of the effects of caffeine, theophylline, cocaine, and atropine (Cammaerts, Rachidi, \& Gosset, 2014), of nicotine (Cammaerts, Gosset, \& Rachidi, 2014), of morphine and quinine (M.-C. Cammaerts \& R. Cammaerts, 2014), of fluoxetine, an 'ISRS' antidepressant (M.-C. Cammaerts \& D. Cammaerts, 2015a), as well as of anafranil, an 'ACT' antidepressant and of efexor, an 'IRSNa' antidepressant (M.-C. Cammaerts \& D. Cammaerts, 2015b), on M. sabuleti as model. Each time, we observed 
effects related to those observed for humans, and brought information as well as precision about effects of the examined substance, of course on M. sabuleti, but clearly leading to presume similar effects for humans and other living organisms. We thus here conduct a similar analysis (employing identical methods for comparative purpose) about potential adverse physiological and ethological effects generated by carbamazepine, the active substance of the drug universally used for treating epileptic persons and those suffering from pain in cerebral nervous, aiming to deduce effects on naturally living organisms, as well as on humans.

\section{Experimental Planning}

The 20 following behavioral and physiological traits were assessed on two or four colonies of M. sabuleti before and after they consumed carbamazepine. A third colony was used to provide 'alien workers'. Most of these traits had previously similarly been examined while studying effects of alkaloids and drugs (see references in the 'Introduction' section).

1) the speed of locomotion (and thus the general activity) through the ants' linear speed,

2) The sinuosity of movement through the ants' angular speed,

3) the precision of reaction through the orientation towards a source of their alarm pheromone,

4) the response to pheromones through the trail following behavior,

5) the "audacity" through the numbers of ants coming onto a test apparatus,

6) food consumption through the numbers of ants coming onto meat food,

7) cognition through the ability in performing a task requiring cognition (moving through chicanes),

8) the caring behavior through the behavior in front of larva removed from the nest,

9) the visual perception through the distinguishing of two colors,

10) the olfactory perception through the distinguishing of two odors,

11) the tactile sensation (or "pain" perception) through the ants' behavior in an uncomfortable situation,

12) the potential aggressiveness against nestmates through ants' behavior in the course of dyadic encountering,

13) the expected aggressiveness against alien ants through ants' behavior in the course of dyadic encountering,

14) the dependence on drug consumption through the numbers of ants choosing food containing the drug,

15) the habituation to the drug consumption through the speed of movement and the orientation to an alarm signal, fourteen days after continuous drug consumption,

16) the visual learning ability through the acquisition of a visual conditioning,

17) the visual memory through the duration of the remembering a learned visual cue,

18) the olfactory learning ability through the acquisition of an olfactory conditioning,

19) the olfactory memory through the duration of the remembering a learned olfactory cue,

20) the decrease of the effects of carbamazepine after its consumption ended i.e. after that carbamazepine had been removed from the food, through the ants' linear and angular speed, and orientation to an alarm signal.

\section{Material and Methods}

\subsection{Collection and Maintenance of the Ants}

The study was made on four colonies of $M$. sabuleti, two ones (labeled 1 and 2) having been devoted to the entire experimental work, two other ones (labeled 3 and 4) having been used only for the study of conditioning acquisition ability and memory. A fifth colony furnished the 'alien workers' required in one experiment. The colonies one and two were collected in an abandoned sandstone quarry located in the Aise valley (Ardenne, Belgium); the colonies three and four were collected at Audregnies, on an abandoned Terril (Terril de Ferrand, Hainaut, Belgium); the fifth colony was collected in an abandoned quarry at Treignes (Ardenne, Belgium). The ants were nesting under stones, in field covered with small plants and brushes. The collected colonies were demographically similar, containing about 600 workers, one or two queens and brood at larval and nymphal stages. They were maintained in the laboratory in artificial nests made of one to three glass tubes half-filled with water, with a cotton-plug separating the ants from the water. These glass tubes were deposited in trays $(34 \mathrm{~cm} \mathrm{x} 23 \mathrm{~cm} \mathrm{x}$ $4 \mathrm{~cm}$ ), the sides of which were covered with talc to prevent the ants from escaping. The trays served as foraging areas, food being delivered into them. The ants were fed with sugar-water provided ad libitum in a small glass tube plugged with cotton, and with pieces of Tenebrio molitor (Linnaeus 1758) larva provided twice a week on a glass 
slide. Temperature was maintained between $18^{\circ} \mathrm{C}$ and $22^{\circ} \mathrm{C}$, humidity at about $80 \%$, these conditions remaining constant over the course of the study. Lighting had a constant intensity of 330 lux while caring for the ants, training and testing them. During other time periods, the lighting was dimmed to 110 lux. The ambient electromagnetic field had an intensity of $2-3 \mu \mathrm{W} / \mathrm{m}^{2}$.

\subsection{Acquisition of Carbamazepine, Realization of Aqueous Solutions for Ants}

Tablets of Tegretol $(200 \mathrm{mg})$, the active substance being carbamazepine, produced by the manufacturer NOVARTIS, were provided by the pharmacist J. Cardon (1050 Brussels). All the other drugs, otherwise labeled, having the same pharmaceutical effects, have also carbamazepine as active substance. The usual amount of carbamazepine given, per day, to humans suffering from epilepsies or pain in cerebral nerves V and VII varies between $100 \mathrm{mg}$ and $800 \mathrm{mg}$. The quantity of water humans ingest could be estimated at one liter per day. So, humans consuming carbamazepine commonly ingest about $300 \mathrm{mg}$ of drug for one liter $(1,000 \mathrm{ml})$ of ingested water. Insects consume about ten less water than mammals. It could so be estimated that the most appropriate solution of carbamazepine to be given to the ants for being in agreement with that commonly consumed by humans would be $300 \mathrm{mg}$ of carbamazepine into $100 \mathrm{ml}$ of water. Therefore, $200 \mathrm{mg}$ of carbamazepine (one Tegretol tablet) were scratched and then dissolved in $66 \mathrm{ml}$ of a saturated solution of brown sugar, the ants' usual liquid food. The concentration in drug of the final solution was thus $200 \mathrm{mg}$ in $66,000 \mathrm{mg}$ of water, so $0.3 \%$ or $3 / 1,000$. This solution was given to the ants, like their usual liquid food, in a small glass tube plugged with cotton, the cotton being refreshed each two days and the entire solution renewed each 14 days. It was checked each day if ants actually consumed the given liquid food containing carbamazepine.

\subsection{Linear and Angular Speed (1, 2), Orientation (3)}

Ants' linear and angular speed was assessed for detecting excitation or sleepiness in the animals. This assessment was made on ants freely moving on their foraging area. Ants' orientation towards an isolated congener's head allows measuring the ants' precision of reaction. An isolated worker's head, with widely opened mandibles, is a source of alarm pheromone identical to that of an alarmed worker, in terms of the dimensions of the emitting source (the mandibular glands' opening) and of the quantity of pheromone emitted (Cammaerts-Tricot, 1973). Each time, such assessment was made on ants of nests 1 and 2 having never consumed carbamazepine, then on ants of these two nests having consumed the drug during two to three days. For each assessment, the movement of ten ants of each nest ( $\mathrm{n}=20$ ants) was analyzed.

Trajectories were recorded manually, using a water-proof marker pen, on a glass slide placed horizontally $3 \mathrm{~cm}$ above the area where the tested individuals were moving. A metronome set at 1 second was used as a timer for assessing the total time of each trajectory. Each trajectory was recorded during 5 to 10 seconds or until the ant reached the stimulus. All the trajectories were then traced, with a water-proof marker pen, onto transparent polyvinyl sheets using the glass slide as the reference model, and the polyvinyl sheets were affixed to a PC monitor screen. The trajectories were analyzed using specifically designed software (Cammaerts, Morel, Martino, \& Warzée, 2012) so that the trajectory parameters could be quantified.

The three used parameters were defined as follows:

The linear speed $(\mathrm{V})$ of an animal is the length of its trajectory divided by the time spent moving along this trajectory. It was measured in $\mathrm{mm} / \mathrm{s}$.

The angular speed (S) (i.e. the sinuosity) of an animal's trajectory is the sum of the angles, measured at each successive point of the trajectory, made by the segment 'point $\mathrm{i}$ - point $\mathrm{i}-1$ ' and the segment 'point $\mathrm{i}$ - point $\mathrm{i}+$ 1', divided by the length of the trajectory. This variable was measured in angular degrees $/ \mathrm{cm}$ (= ang. deg. $/ \mathrm{cm}$ ).

The orientation $(\mathrm{O})$ of an animal towards a given point (here an ant's head) is the sum of the angles, measured at each successive point of the registered trajectory, made by the segment 'point $i$ of the trajectory - given point' and the segment 'point $\mathrm{i}$ - point $\mathrm{i}+1$ ' divided by the number of measured angles. This variable was measured in angular degrees ( $=$ ang. deg). When such a variable $(\mathrm{O})$ equals $0^{\circ}$, the observed animal perfectly orients itself towards the point; when $\mathrm{O}$ equals $180^{\circ}$, the animal fully avoids the point; when $\mathrm{O}$ is lower than $90^{\circ}$, the animal has a tendency to orient itself towards the point; when $\mathrm{O}$ is larger than $90^{\circ}$, the animal has a tendency to move in a direction that deviates from the point.

Each distribution of 20 measurements was characterized by its median and its quartiles (since being not Gaussian; Table 1, table lines 1,2,3), and the distribution of values obtained for ants having consumed carbamazepine was statistically compared to that previously obtained for the same ants having never consumed that drug, using the non-parametric $\chi^{2}$ test (Siegel and Castellan, 1989). The significance threshold was set to $\alpha=0.05$. 
Table 1. Effect of carbamazepine on six ants' physiological traits

\begin{tabular}{|c|c|c|c|c|}
\hline Traits & Variable assessed & No drug consumed & Drug consumed & Statistics \\
\hline Speed $n=20$ & Linear speed $\mathrm{mm} / \mathrm{sec}$ & $14.4(13.1-15.5)$ & $9.7(8.8-10.4)$ & $\mathrm{P}<0.001$ \\
\hline Sinuosity $\mathrm{n}=20$ & Sinuosity ang.deg./cm & $104(85-113)$ & $177(154-205)$ & $\mathrm{P}<0.001$ \\
\hline $\begin{array}{l}\text { Precision of } \\
\text { a reaction } n=20\end{array}$ & $\begin{array}{l}\text { Orientation to an alarm } \\
\text { signal; ang.deg. }\end{array}$ & $35.8(30.2-44.4)$ & $67.2(56.1-85.8)$ & $\mathrm{P}<0.001$ \\
\hline $\begin{array}{l}\text { Response to } \\
\text { pheromones } \mathrm{n}=40\end{array}$ & $\begin{array}{l}\text { Trail following behavior } \\
\left(\mathrm{n}^{\circ} \text { of arcs walked) }\right.\end{array}$ & $\begin{array}{l}\text { C: } 1(1-1) \\
\mathrm{T}: 12.0(6.0-18.0)^{*}\end{array}$ & $\begin{array}{l}\mathrm{C}: 1(0-1) \\
\mathrm{T}: 12.0(6.5-21.3)\end{array}$ & $\begin{array}{l}\text { NS } \\
\text { NS }\end{array}$ \\
\hline audacity $\quad n=20$ & $\begin{array}{l}\mathrm{N}^{\circ} \text { of ants on a tower } \\
\text { (mean, extremes) }\end{array}$ & $2.5(0-6)$ & $0.5(0-2)$ & $\mathrm{P}=0.00007$ \\
\hline $\begin{array}{l}\text { Food consumption } \\
\mathrm{n}=20\end{array}$ & $\begin{array}{l}\mathrm{N}^{\circ} \text { of ants eating meat } \\
\text { (mean, extremes) }\end{array}$ & $3.5(1-7)$ & $1.15(0-3)$ & $\mathrm{P}=0.00002$ \\
\hline
\end{tabular}

\subsection{Trail Following Behavior (3)}

This behavior was assessed for examining the ants' response to pheromones. The trail pheromone of Myrmica ants is produced by the workers' poison gland. Ten of these glands were isolated in $0.5 \mathrm{ml}(500 \mu \mathrm{l})$ hexane and stored for $15 \mathrm{~min}$ at $-25{ }^{\circ} \mathrm{C}$. To perform one experiment, $0.05 \mathrm{ml}(50 \mu \mathrm{l})$ of the solution was deposited, using a metallic normograph pen, on a circle $(\mathrm{R}=5 \mathrm{~cm})$ pencil drawn on a piece of white paper and divided into 10 angular degrees arcs (= ang. deg.). One minute after being prepared, the piece of paper with the artificial trail was placed in the ants' foraging area. When an ant came into contact with the trail, its movement was observed (Figure 1A). Its response was assessed by the number of arcs of 10 angular degrees it walked without departing from the trail, even if it turned back while walking on the trail. If an ant turned back when coming in front of the trail, its response was assessed as "zero arc walked"; when an ant crossed the trail without following it, its response equaled "one walked arc". Before testing the ants on a trail, they were observed on a "blank" circumference imbibed with $50 \mu \mathrm{l}$ of pure hexane, and the control numbers of walked arcs were so obtained (Table 1, table line 4, $\mathrm{C}=$ control, $\mathrm{T}=$ test). On such experimental trails, Myrmica workers do not deposit their trail pheromone because they do so only after having found food or a new nest site. Each time, these manipulations were made firstly on ants of nests 1 and 2 having never consumed carbamazepine, then on the same colonies having consumed this drug for four days. For each control and test experiment, 20 individuals of each two used colonies were observed $(n=40)$. Each distribution of values was characterized by its median and quartiles (since being not Gaussian; Table 1, table line 3). The distributions of values obtained for ants having consumed carbamazepine were compared to the corresponding ones obtained for ants having never consumed this drug, using the non parametric $\chi^{2}$ test (Siegel \& Castellan, 1989).

\subsection{Ants' "Audacity" (5)}

Before the ants consumed carbamazepine, and three days after they had consumed that drug, a cylindrical tower built in strong white paper (Steinbach ${ }^{\circledR}$, height $=4 \mathrm{~cm}$; diameter $=1.5 \mathrm{~cm}$ ) was set on the ants' foraging area (Figure 1B), and the ants present on it, at any place, were counted 10 times, in the course of $10 \mathrm{~min}$. The mean and the extreme values of the obtained values were established each time and the two series of values were compared using the non parametric Mann-Whitney U test (Siegel \& Castellan, 1989; Table 1, table line 5).

\subsection{Ants' Food Consumption (6)}

Before the ants consumed carbamazepine, and after they had consumed that drug for three days, the workers present on the meat food (pieces of T. molitor larva) at a time ants must be fed were counted 10 times in the 
course of $10 \mathrm{~min}$. The numbers obtained for the two kinds of food intake (with no drug, then with drug) were statistically compared using the Mann-Whitney U test (same reference as above), and the mean as well as the extreme values of the recorded numbers were established (Table 1, table line 6).
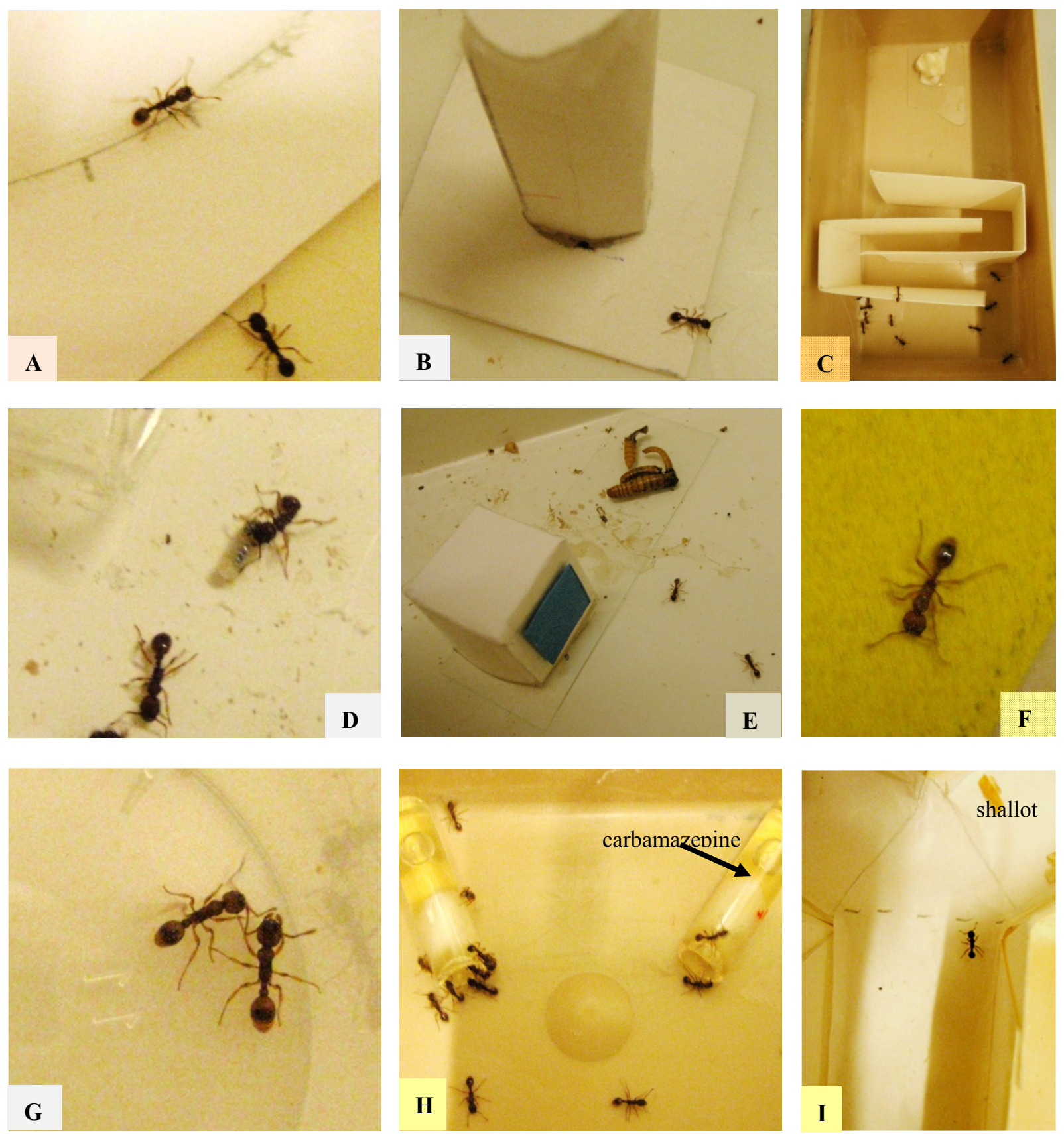

Figure 1. Some views of the experiments made on ants consuming carbamazepine

A: an ant correctly following a trail; B: an ant moving away from a risky apparatus; $\mathrm{C}$ : ants not inclined in moving through chicanes; D: an ant taking care of a larva; E: ants trained to visual cues; F: an ant moving with difficulties, but yet progressing, on a rough uncomfortable bottom; G: two congeners, one of them opening its mandibles, a somewhat aggressive behavior; $\mathrm{H}$ : ants chose the sugar food free of carbamazepine, presenting so no dependence on the drug consumption; I: even after $72 \mathrm{hrs,} \mathrm{an} \mathrm{ant,} \mathrm{previously} \mathrm{trained} \mathrm{to} \mathrm{pieces} \mathrm{of} \mathrm{shallots,} \mathrm{chose} \mathrm{the} \mathrm{branch} \mathrm{of}$ the $\mathrm{Y}$ containing such pieces. 


\subsection{An Ants' Cognitive Ability Requiring No Memory (7)}

This ability was assessed on ants of nests 1 and 2 first while these nests did not receive carbamazepine, then five days after they had continuously that drug in their liquid food. The assessment was made using an adequate experimental apparatus schematically presented in the figure 3 of Cammaerts et al. (2014b) and here shown in Figure $1 \mathrm{C}$. This apparatus consisted in a small tray $(15 \mathrm{~cm} \times 7 \mathrm{~cm} \times 4.5 \mathrm{~cm})$ inside of which two pieces of white extra strong paper (Steinbach ${ }^{\circledR}, 12 \mathrm{~cm} \mathrm{x} 4.5 \mathrm{~cm}$ ), duly twice folded, were inserted in order to create a way with four chicanes between a narrow (too narrow for 15 ants) initial space (initial loggia) and a larger area (free loggia). Two such experimental apparatus were built and used, each one, for one of the two nests. Each time, for each nest and each feeding situation, 15 ants were collected from their colony and set all together, at the same time, in the initial loggia of the apparatus, and those located in this loggia as well as in the free loggia were counted after $0,5,10,15$ and $20 \mathrm{~min}$ (Table 2, table line 1). The numbers obtained for ants consuming carbamazepine were statistically compared to those previously obtained for ants having never received this substance using the non parametric Wilcoxon test (Siegel \& Castellan, 1989).

Table 2. Effect of carbamazepine on five other ants' physiological traits

\begin{tabular}{|c|c|c|c|c|c|c|c|c|c|c|c|c|c|c|c|}
\hline \multirow{4}{*}{$\begin{array}{l}\text { Trait examined } \\
\text { Cognitive ability } \\
\text { requiring no memory }\end{array}$} & \multirow{2}{*}{$\begin{array}{c}\text { Variable assessed } \\
\text { time: }\end{array}$} & \multicolumn{7}{|c|}{ No drug consumed } & \multicolumn{7}{|c|}{ Drug consumed } \\
\hline & & \multirow[t]{3}{*}{$\mathrm{t}=$} & \multirow{3}{*}{$\begin{array}{r}0 \\
21 \\
0\end{array}$} & \multirow{3}{*}{$\begin{array}{r}5 \\
12 \\
3\end{array}$} & \multirow{3}{*}{$\begin{array}{r}10 \\
17 \\
3\end{array}$} & \multirow{3}{*}{$\begin{array}{r}15 \\
15 \\
4\end{array}$} & \multirow{2}{*}{\multicolumn{2}{|c|}{$\begin{array}{l}20 \\
13\end{array}$}} & \multirow[t]{3}{*}{$\mathrm{t}=$} & \multirow{3}{*}{$\begin{array}{r}0 \\
22 \\
0\end{array}$} & \multirow{3}{*}{$\begin{array}{r}5 \\
19 \\
0\end{array}$} & \multirow{3}{*}{$\begin{array}{r}10 \\
24 \\
0\end{array}$} & \multirow{3}{*}{$\begin{array}{r}15 \\
21 \\
0\end{array}$} & \multirow{3}{*}{\multicolumn{2}{|c|}{$\begin{array}{r}20 \\
17 \\
0\end{array}$}} \\
\hline & \# ants in the small loggia & & & & & & & & & & & & & & \\
\hline & in the free loggia & & & & & & 6 & & & & & & & & \\
\hline \multirow[t]{2}{*}{ Brood caring } & time: & $\mathrm{t}=$ & 0 & 2 & 4 & 6 & 8 & $10^{\prime}$ & $\mathrm{t}=$ & 0 & 2 & 4 & 6 & 8 & $10^{\prime}$ \\
\hline & \# of 10 larvae not re-entered & & 10 & 8 & 5 & 3 & 1 & 0 & & 10 & 8 & 6 & 4 & 2 & 0 \\
\hline \multirow{6}{*}{ Tactile perception } & time: & $\mathrm{t}=$ & 0 & 2 & 4 & 6 & 8 & $10^{\prime}$ & $\mathrm{t}=$ & 0 & 2 & 4 & 6 & 8 & $10^{\prime}$ \\
\hline & \# ants in the initial zone & & 24 & 19 & 18 & 16 & 20 & 19 & & 20 & 19 & 19 & 11 & 11 & 10 \\
\hline & in the rough zone & & 0 & 5 & 5 & 5 & 3 & 5 & & 4 & 5 & 4 & 7 & 6 & 5 \\
\hline & in the large zone & & 0 & 0 & 1 & 3 & 1 & 0 & & 0 & 0 & 1 & 6 & 7 & 9 \\
\hline & linear speed, $\mathrm{mm} / \mathrm{sec}$ & \multicolumn{7}{|c|}{$3.7(3.2-4.1)$} & \multicolumn{7}{|c|}{$7.8(6.9-8.4)$} \\
\hline & sinuosity, ang.deg./cm & \multicolumn{7}{|c|}{$318(277-379)$} & \multicolumn{7}{|c|}{$152(133-188)$} \\
\hline \multirow{6}{*}{ Aggressiveness } & levels of aggressiveness & \multicolumn{4}{|c|}{ vs congeners } & \multicolumn{3}{|c|}{$v s$ alien ants } & \multicolumn{4}{|c|}{ vs congeners } & \multicolumn{3}{|c|}{ vs alien ants } \\
\hline & 0 & \multicolumn{4}{|c|}{71} & \multicolumn{3}{|c|}{0} & \multicolumn{4}{|c|}{42} & \multicolumn{3}{|c|}{7} \\
\hline & 1 & \multicolumn{4}{|c|}{38} & & 17 & & & 66 & & & & 2 & 0 \\
\hline & 2 & & 0 & & & & 49 & & & 43 & & & & 5 & 4 \\
\hline & 3 & & 0 & & & & 102 & & & 5 & & & & 5 & 1 \\
\hline & 4 & & 0 & & & & 22 & & & 0 & & & & 3 & 6 \\
\hline
\end{tabular}

Carbamazepine appeared to affect the ants' cognition (no ant reached the free zone, through chicanes), to have no effect on their brood caring behavior, to affect their tactile perception (they were less reluctant in moving on a rough bottom), and to induce some aggressiveness towards congeners while reducing that towards alien ants.

\subsection{Ants' Caring Behavior (8)}

This trait was examined, for nests 1 and 2, before the ants consumed carbamazepine, then six days after they had consumed that drug. Each time, a few larvae were removed from the inside of the nest and deposited in front of the nest tube entrance. Five of them were carefully observed, as well as the ants' behavior in front of the larvae (Figure 1D). The numbers of the five observed larvae still remaining out of the nest were counted after $0,2,4,6$, 8, 10 minutes, and the numbers recorded for each two colonies were added (Table 2, table line 2). The results obtained for ants consuming carbamazepine were compared to those similarly obtained for ants having never consumed that drug using the non parametric Wilcoxon test (Siegel \& Castellan, 1989).

\subsection{Ants' Visual Perception (9)}

For examining this sensorial ability, ants of nests 1 and 2 (having consumed carbamazepine for seven days) were trained with their own training apparatus and then tested using another similar outfit, each colony having again its own test apparatus. The apparatus consisted of a glass slide $(2.6 \mathrm{~cm} \times 7.6 \mathrm{~cm})$ with a cube $(2 \mathrm{~cm} \times 2 \mathrm{~cm} \times 2 \mathrm{~cm})$ 
made of extra strong white paper (Steinbach $\left.{ }^{\circledR}\right)$ placed at an end. On one face of the cube was a blue square $(1.5 \mathrm{~cm}$ $\mathrm{x} 1.5 \mathrm{~cm}$ ) and on the opposite face a yellow identical square. The squared cues were cut from strong colored paper (Canson $\left({ }^{\circledR}\right)$ the colors of which had previously been analyzed for their wavelengths reflection (Cammaerts, 2007, Cammaerts \& Cammaerts, 2009). During training, a T. molitor larvae cut in two pieces was tied to the end of the glass slide where there was no cube, so at $2-4 \mathrm{~cm}$ from the cube (Figure 1E). During the tests, no meat was placed on the apparatus.

Four tests were performed six days, as well as nine days, after the ants were exposed to (and so could see) the adequate apparatus on their foraging area, the apparatus being provided with a cube free of any colored cues (first test), or a cube with a blue square (second test), or a cube with a yellow square (third test), or a cube with a blue and a yellow cues (fourth test). Each time, the ants present on the glass slide were counted 10 times, for each of the two colonies, and the mean value of the 20 counts was calculated (Table 3, upper part). The four kinds of counts were compared to one another using the non parametric test of Wilcoxon (Siegel \& Castellan, 1989). If the ants coming onto the glass slide in the presence of one, or the other, or the two colored cues were more numerous than those coming in the presence of a cube free of any cue, then the ants had been able to visually perceive the colored cues (Cammaerts \& Rachidi, 2009, Cammaerts et al., 2011).

Table 3. Visual and olfactory perception of ants under carbamazepine consumption

\begin{tabular}{ccccc}
\hline Visual perception & no cue & blue cue & yellow cue & the two cues \\
\hline after 6 days & 0.15 & 0.90 & 0.85 & 1.15 \\
after 9 days & 0.00 & 0.90 & 0.95 & 1.10
\end{tabular}

\begin{tabular}{ccccc} 
Olfactory perception & no odor & thyme & estragon & the two odors \\
\hline after 6 days & 0.15 & 0.80 & 1.15 & 0.75 \\
after 9 days & 0.00 & 0.75 & 0.85 & 1.05
\end{tabular}

After having been in presence of two visual cues and two odorous ones, for six, then nine days, ants consuming carbamazepine were tested in front of each of these cues. They reacted to every presented cue but their reaction to the olfactory cues was somewhat lower than that to the visual cues, what is not usual for the tested species. More experimental and statistical details are given in the text.

\subsection{Ants' Olfactory Perception (10)}

For examining this sensorial ability, ants of nests 1 and 2 (having consumed carbamazepine four seven days) were trained by way of an own experimental apparatus. Afterward they were tested using another, similar apparatus, each colony having also its own test apparatus. The apparatus consisted of a piece of extra strong white paper (Steinbach ${ }^{\circledR}, 12 \mathrm{~cm}$ X $6 \mathrm{~cm}$ ) orthogonally folded lengthwise to present a horizontal and a vertical part. A small glass tube (length: $7 \mathrm{~cm}$; diameter: $1 \mathrm{~cm}$ ) was inserted into a hole (diameter: $1.2 \mathrm{~cm}$ ) cut in the middle of the vertical part very close to the base. The glass tube was placed in the foraging area with the opening in the middle of the apparatus. A schema of such an apparatus is given in Cammaerts and Rachidi (2009). During training, the glass tube was filled with sugared water (the reward) and closed with a cotton plug, while pieces of thyme and pieces of estragon were deposited on a glass slide cover slip $(2.2 \mathrm{~cm} \times 2.2 \mathrm{~cm})$ located respectively on the left and on the right horizontal ends of the experimental apparatus. The experimental apparatus used for testing was free of odorous plants, or provided with thyme, or with estragon, or with both cues depending on the experiments, and the glass tube was empty (i.e., no reward was given during tests), but closed with a cotton plug to prevent entry.

Four tests were so performed six days, as well as nine days, after the ants were exposed to (and so could perceive) the two odors, together with their sugar food, on their foraging area, using the four here above cited experimental designs. During each series of tests, the ants coming onto the apparatus were counted 10 times, for each of the two used colonies. Each time, the mean value of the 20 counts was calculated (Table 3, lower part), while the four kinds of counts were compared to one another using the non parametric test of Wilcoxon (Siegel \& Castellan, 1989). If the ants coming onto the apparatus in the presence of one, or the other, or the two olfactory cues were more numerous than those coming in the absence of such cues, then the ants had been able to olfactory perceive the odorous cues (Cammaerts \& Rachidi, 2009, Cammaerts et al., 2011). 


\subsection{Ants' Tactile Sensation (Presumed 'Pain Sensation') (11)}

It was tempted to assess this physiological trait by setting ants in an experimental apparatus made of a small tray $(15 \mathrm{~cm} \times 7 \mathrm{~cm} \times 4.5 \mathrm{~cm})$ into which a piece $(3 \mathrm{~cm} \times 11 \mathrm{~cm})$ of rough emery paper (number 280) was duly folded (11 $\mathrm{cm}: 2 \mathrm{~cm}+7 \mathrm{~cm}+2 \mathrm{~cm}$ ) and tied to the bottom and the border of the tray, so dividing the tray in three zones: a small initial smooth zone ( $3 \mathrm{~cm}$ long), a zone ( $3 \mathrm{~cm}$ long) on which ants' walking should be uncomfortable, and a large smooth zone ( $9 \mathrm{~cm}$ long) for inciting the ants crossing the uncomfortable zone. Two such apparatus were used, one for nest 1 , the other for nest 2 . The ants were tested before they consumed carbamazepine, then eight days after they had continuously received that drug. Each time, 12 ants were set, all together, at the same time, in the small initial zone. The ants present in each of the three zones of the apparatus were counted after $0,2,4,6,8,10$ min, and the linear as well as the angular speed of 12 ants for each two tested colonies (so $n=24)$ moving on the rough paper were assessed using the method briefly explained in point 3.3 (Figure 1F; Table 2, table line 3). The numbers of ants obtained for ants having consumed carbamazepine were statistically compared to those previously obtained for ants of the same colonies having never ingested that drug, using the non parametric Wilcoxon test (Siegel \& Castellan, 1989), while the linear and angular speed of such ants were statistically compared using the non parametric $\chi^{2}$ test (same reference as above).

\subsection{Ants' Aggressiveness Towards Congeners or Alien Workers $(12,13)$}

This trait was quantified before the ants of nests 1 and 2 consumed carbamazepine, then nine days after they had continuously consumed that drug. Ants' potential aggressiveness towards nestmates as well as expected aggressiveness towards alien workers (i.e. belonging to another colony) was assessed in the course of dyadic encounters of five ants of each of the two used colonies, the encountering being conducted in a small glass (base diameter $=3 \mathrm{~cm}$, top diameter $=4 \mathrm{~cm}$, height $=5 \mathrm{~cm}$ ), the borders of which had been slightly covered with talc. Each time (in total ten encounters with nestmates and ten encounters with alien workers, each time before then under carbamazepine consumption), the ant of the presently used colony was observed for 3 minutes and its meetings with the other ant were characterized by the numbers of times it did nothing (level 0 of aggressiveness), it touched the other ant with its antennae (level 1), it opened its mandibles in front of the other ant (level 2; Figure 1G), it gripped and/or pulled the other ant (level 3), and it tried to sting or stung the other ant (level 4). The numbers recorded for each two used colonies were added (Table 2, table line 4), and the results obtained for ants consuming carbamazepine were compared to those obtained for ants having never consumed that drug, using the non parametric $\chi^{2}$ test (Siegel \& Castellan, 1989).

\subsection{Ants' Dependence on Carbamazepine Consumption (14)}

After the ants had continuously consumed carbamazepine during ten days, an experiment was performed for examining if they acquired some dependence on the consumed drug. Fifteen ants of each two used colonies were transferred into a small tray $(15 \mathrm{~cm} \times 7 \mathrm{~cm} \times 5 \mathrm{~cm})$, the borders of which had been covered with talc and in which two tubes $(\mathrm{h}=2.5 \mathrm{~cm}$, diam. $=0.5 \mathrm{~cm})$ were laid, one containing sugar water, the other sugar water and carbamazepine (the same solution as that used for the whole experimental work), each tube being plugged with cotton. In one of the trays, the tube containing the drug was located on the right; in the other tray, it was located on the left (Figure 1H). The ants drinking each liquid food were counted 12 times, the mean values being then established for each kind of food (Table 4, table line1). They were statistically compared to the values expected if ants randomly went drinking each kind of food, using the non parametric goodness of fit $\chi^{2}$ test (Siegel \& castellan, 1989).

Table 4. Dependence on and habituation to carbamazepine consumption.

\begin{tabular}{|c|c|c|}
\hline Effect studied & Variable assessed & Numerical results \\
\hline $\begin{array}{l}\text { Dependence } \\
(12 \text { counts })\end{array}$ & $\begin{array}{l}\text { Ants on sugar water and on sugar } \\
\text { water }+ \text { carbamazepine }\end{array}$ & $\begin{array}{l}\text { Nest } 1: 67 \text { ants and } 25 \text { ants } \rightarrow 72.83 \% \text { and } 27.17 \% \\
\text { Nest } 2: 35 \text { ants and } 94 \text { ants } \rightarrow 27.13 \text { and } 72.87 \%\end{array}$ \\
\hline \multirow[t]{2}{*}{ habituation } & $\begin{array}{l}\text { linear speed }(\mathrm{mm} / \mathrm{sec}) \\
\text { angular speed (ang.deg/cm) }\end{array}$ & $\begin{array}{l}\text { vs control: } \mathrm{P}<0.001 ; \text { vs two days: NS } \\
\text { vs control: } \mathrm{P}<0.001 ; \text { vs two days: NS }\end{array}$ \\
\hline & $\begin{array}{l}\text { orientation towards an alarm signal } \\
\text { (ang.deg.) }\end{array}$ & vs control: $\mathrm{P}<0.001 ;$ vs two days: NS \\
\hline
\end{tabular}


Experimental and statistical details are given in the text. Briefly, ants developed no dependence on carbamazepine consumption, and presented no habituation to that drug as for their locomotion and precision of reaction.

\subsection{Ants' Habituation to the Drug Consumption (15)}

Twelve days after the ants had continuously consumed carbamazepine, their linear and angular speed, as well as their orientation towards an isolated worker's head, were assessed (Table 4, table line 2). The results were compared to the control ones and to those obtained after two to three days of drug consumption using the non parametric $\chi^{2}$ test (Siegel \& Castellan, 1989).

\subsection{Ants' Visual and Olfactory Operant Conditioning Ability and Memory (16, 17, 18, 19)}

Briefly, at a given time, either a green hollow cube (after 14 days of carbamazepine consumption) or pieces of dried shallots (after 21 days of that drug consumption) were set above the pieces of T. molitor larva, this time tied to the supporting piece of glass. The ant (of nests 1 and 2 as well as of nests 3 and 4) so underwent either visual or olfactory operant conditioning. Each time, tests were performed, in the course of time, while the ants were expected acquiring conditioning, then, after having removed the green cube or the pieces of shallots, while the ants were expected to partly lose their conditioning.

In detail, ants were collectively visually trained to a hollow green cube constructed of strong paper (Canson ${ }^{\circledR}$ ) according to the instructions given in Cammaerts and Nemeghaire (2012) and set over the meat food which served as a reward. The color has been analyzed to determine its wavelengths reflection (Cammaerts, 2007). Only the ceiling of the cubes was filled, this allowing ants entering the cube. Choosing the green cube was considered as giving the 'correct' choice when ants were tested as explained below. The ants were olfactory conditioned by setting pieces of dried shallots aside the tied pieces of T. molitor larva. Choosing the pieces of shallots was considered as giving the 'correct' choice when ants were tested as explained below.

Ants were individually tested in a Y-shaped apparatus (Figure 1I) constructed of strong white paper according to the instructions given in Cammaerts et al. (2011), and set in a small tray $(30 \mathrm{~cm} \times 15 \mathrm{~cm} \times 4 \mathrm{~cm})$, apart from the experimental colony's tray. Each colony had its own testing device. The apparatus had its own bottom and the sides were slightly covered with talc to prevent the ants from escaping. In the Y-apparatus, the ants deposited no trail since they were not rewarded. However, they could utilize other chemical secretions as traces. As a precaution, the floor of each Y-apparatus was changed between tests. The Y-apparatus was provided with either a green cube, or pieces of dried shallots, in one or the other branch. Half of the tests were conducted with the cube, or the odorous plant, in the left branch and the other half with the cube, or the odorous plant, in the right branch of the Y maze, and this was randomly chosen. Control experiments had previously been made on never conditioned ants and on trained ants of colonies having never received carbamazepine (Table 5: * from Cammaerts et al., 2011: ** from Cammaerts et al., 2014b). This must be done because, once an animal is conditioned to a given stimulus, it becomes no longer naïve for such an experiment. It was so impossible to perform, on the same ants, conditioning without then with carbamazepine in the ants' food. The only solution was thus to use previous results obtained in the course of identical experiments made on very similar colonies never fed with any drug.

To conduct a test on a colony, 10 workers - randomly chosen from the workers of that colony - were transferred one by one onto the area at the entrance of the Y-apparatus. Each transferred ant was observed until it turned either to the left or to the right in the Y-tube, and its choice was recorded. Only the first choice of the ant was recorded and this only when the ant was entirely under the cube, i.e. beyond a pencil drawn thin line indicating the entrance of a branch (Figure 1I). Afterwards, the ant was removed and transferred into a polyacetate cup, in which the border was covered with talc, until 10 ants were so tested, this avoiding testing the same ant twice. All the tested ants were then placed back on their foraging area. For each experiment, the numbers of ants, among $n$ $=10+10=20$ for nests 1 and 2 , as well as $n=10+10=20$ for nests 3 and 4 , which turned towards the "correct" green cube or pieces of shallots, or went to the "wrong" empty branch of the Y were recorded. The percentage of correct responses for the tested ant population was so established (Table 5). The results obtained for ants that have consumed carbamazepine were compared to previous results obtained for ants that had never consumed that substance, using the non parametric Wilcoxon test (Siegel \& Castellan, 1989). The value of N, T, and $\mathrm{P}$, according to the nomenclature given in the here above reference, are defined in Table 5 and the results section. 
Table 5. Effect of carbamazepine on ants' visual and olfactory conditioning acquisition, and memory

\begin{tabular}{|c|c|c|c|c|c|c|}
\hline \multirow{2}{*}{ Trait assessed } & \multirow{2}{*}{$\begin{array}{l}\text { Time } \\
\text { (hrs) }\end{array}$} & \multirow{2}{*}{$\begin{array}{l}\text { Control } \\
\text { (no drug) }\end{array}$} & \multicolumn{2}{|c|}{ + carbamazepine } & \multirow{2}{*}{$\begin{array}{c}\text { + carbamazepine } \\
\text { all the nests }\end{array}$} & \multirow{2}{*}{ statistics } \\
\hline & & & nests 1 and 2 & nests 3 and 4 & & \\
\hline \multirow{7}{*}{ Visual conditioning } & & ${ }^{*} \mathrm{C} 50 \%$ & & & & \multirow{7}{*}{$\begin{array}{c}\mathrm{N}=6 \\
\mathrm{~T}=21 \\
\mathrm{P}=0.016\end{array}$} \\
\hline & 7 & $* * 55 \%$ & $60 \%$ & $60 \%$ & $60 \%$ & \\
\hline & 24 & $60 \%$ & $70 \%$ & $70 \%$ & $70 \%$ & \\
\hline & 31 & $60 \%$ & $70 \%$ & $70 \%$ & $70 \%$ & \\
\hline & 48 & $65 \%$ & $75 \%$ & $75 \%$ & $75 \%$ & \\
\hline & 55 & $65 \%$ & $80 \%$ & $80 \%$ & $80 \%$ & \\
\hline & 72 & $70 \%$ & $80 \%$ & $80 \%$ & $80 \%$ & \\
\hline \multirow{6}{*}{ Visual memory } & 7 & $* * 65 \%$ & $80 \%$ & $80 \%$ & $80 \%$ & \multirow{6}{*}{$\begin{array}{c}\mathrm{N}=6 \\
\mathrm{~T}=21 \\
\mathrm{P}=0.016\end{array}$} \\
\hline & 24 & $75 \%$ & $75 \%$ & $80 \%$ & $77.5 \%$ & \\
\hline & 31 & $70 \%$ & $70 \%$ & $80 \%$ & $75 \%$ & \\
\hline & 48 & $70 \%$ & $80 \%$ & $75 \%$ & $77.5 \%$ & \\
\hline & 55 & $70 \%$ & $75 \%$ & $85 \%$ & $80 \%$ & \\
\hline & 72 & $70 \%$ & $75 \%$ & $80 \%$ & $77.5 \%$ & \\
\hline \multirow{7}{*}{ Olfactory conditioning } & & ${ }^{*} \mathrm{C} 50 \%$ & & & & \multirow{7}{*}{$\begin{array}{c}\mathrm{N}=6 \\
\mathrm{~T}=21 \\
\mathrm{P}=0.016\end{array}$} \\
\hline & 7 & $* * 55 \%$ & $80 \%$ & $80 \%$ & $80 \%$ & \\
\hline & 24 & $65 \%$ & $85 \%$ & $80 \%$ & $82.5 \%$ & \\
\hline & 31 & $70 \%$ & $80 \%$ & $90 \%$ & $85 \%$ & \\
\hline & 48 & $75 \%$ & $90 \%$ & $80 \%$ & $85 \%$ & \\
\hline & 55 & $80 \%$ & $85 \%$ & $90 \%$ & $87.5 \%$ & \\
\hline & 72 & $80 \%$ & $90 \%$ & $80 \%$ & $85 \%$ & \\
\hline \multirow{6}{*}{ Olfactory memory } & 7 & $* * 65 \%$ & $90 \%$ & $85 \%$ & $87.5 \%$ & \multirow{6}{*}{$\begin{array}{c}\mathrm{N}=6, \\
\mathrm{~T}=21 \\
\mathrm{P}=0.016\end{array}$} \\
\hline & 24 & $60 \%$ & $80 \%$ & $75 \%$ & $77.5 \%$ & \\
\hline & 31 & $60 \%$ & $80 \%$ & $75 \%$ & $77.5 \%$ & \\
\hline & 48 & $55 \%$ & $65 \%$ & $80 \%$ & $72.5 \%$ & \\
\hline & 55 & $55 \%$ & $80 \%$ & $80 \%$ & $80 \%$ & \\
\hline & 72 & $55 \%$ & $75 \%$ & $65 \%$ & $70 \%$ & \\
\hline
\end{tabular}

That drug obviously largely increased these ants' abilities, i.e. their conditioning acquisition as well as their memory.

\subsection{Decrease of the Effects of the Drug, after Its Consumption Ended (20)}

Four weeks (28 days) after that the ants had continuously consumed carbamazepine, the liquid food containing the drug was removed from the ants' tray and replaced by sugar water free of any drug. This change was made at a given recorded time. After that, the ants' angular speed and their orientation towards an isolated worker's head were assessed after successive given time periods (Figure 2). The results revealed the decrease of the effects of the drug, on ants. Their statistical significance could be estimated via the non parametric $\chi^{2}$ test (Siegel \& Castellan, 1989).

\section{Results}

\subsection{Speed (1) and Sinuosity (2) of Movement}

After two days of carbamazepine consumption, the ants moved slowly, often stopped, turned to their right and their left, came back on their way. The obtained numerical results reflected these observations. Under carbamazepine consumption, the ants' linear speed equaled $9.7 \mathrm{~mm} / \mathrm{sec}$ instead of $14.4 \mathrm{~mm} / \mathrm{sec}$ under normal diet, and the 
sinuosity equaled 177 ang. deg./cm instead of 104 ang. deg./cm (Table 1, table lines 1 and 2). The observed differences were statistically significant: linear speed: $\chi^{2}=36.5$, $\mathrm{df}=2, \mathrm{P}<0.001$; angular speed: $\chi^{2}=26.74$, $\mathrm{df}=$ $2, \mathrm{P}<0.001$. Under carbamazepine consumption, the ants foraged only occasionally, came seldom, with difficulty, onto the food sites, and took a rather long time period for re-entering their nest.

\subsection{Orientation to an Alarm Signal (3)}

This ants' ability acquired while being young, was affected as soon as after two days of carbamazepine consumption. The ants perceived the alarm signal, their stopped, left their head, and sometimes opened their mandibles. They moved a moment towards the alarm signal, then either they came back on their way, or went on walking but not efficiently towards the alarm signal, or moved beyond this signal. The numerical results confirmed this observation: under carbamazepine consumption, the ants' orientation to an alarm signal equaled $67.2 \mathrm{ang}$. deg. while under normal diet, this trait equaled 35.8 ang. deg. (Table 1, table line 3 ) The difference between the two values were statistically significant: $\chi^{2}=18.44, \mathrm{df}=2, \mathrm{P}<0.001$.

\subsection{Trail following Behavior (4)}

Either under normal diet or under carbamazepine consumption, the ants did not follow a blank circular line. Under each of these two kinds of diet, the ants very well followed a trail (concentration 1 gland/trail; $\mathrm{R}=5 \mathrm{~cm}$ ) and reached identical score (normal diet: $12 \operatorname{arcs}$ of $10^{\circ}$; under carbamazepine: $12 \operatorname{arcs}$ of $10^{\circ}$; statistical evaluation: $\chi^{2}$ $=2.06, \mathrm{df}=4$, NS; Table 1, table line 4). The ants consuming the studied drug were carefully observed. Few ants came onto the trail, and they moved on the trail less rapidly than usually. But they obviously perceived the trail pheromone, and correctly responded to it (Figure 1A). It can also added that under normal diet, the maximum score of trail following behavior obtained was 30 arcs of $10^{\circ}$, while under carbamazepine consumption two ants reached respectively the score of 64 and 59 arcs of $10^{\circ}$. So, carbamazepine consumption did not affect the individuals' perception of nestmates' pheromones, nor their responses to these pheromones. It could only be observed that the response may be slightly slower that usually, but not lower.

\section{4 "Audacity" (5)}

This trait was affected by carbamazepine consumption. In front of the presented "risky' apparatus, the ants consuming this drug, moving slowly, avoided the apparatus, turned back on their way, or came on the apparatus and soon went away from it (Figure 1B). The numerical results confirmed this observation (Table 1, table line 5). Under normal diet, meanly 2.5 ants were counted on the "risky" apparatus, while under carbamazepine consumption, only 0.5 ants were so counted. The difference between the two series of counts was statistically significant $(\mathrm{U}=: 74, \mathrm{Z}=3.54, \mathrm{P}=0.0007)$.

\subsection{Food Consumption (6)}

As said here above, under carbamazepine consumption, the ants did not forage a lot of, moved slowly and not often reached the food sites. Once on the food, these ants eat during a rather long time. However, the numbers of ants consuming carbamazepine counted on the food sites were statistically lower that those counted when no drug was added to the ants' sugar food (Table 1 , table line 6 ; $\mathrm{U}=49.5, \mathrm{Z}=4.25, \mathrm{P}=0.00002$ ). It can be concluded that carbamazepine affected the individuals' research, capture, localization of food, while it apparently did not impact their food ingestion.

\subsection{A Cognitive Ability Requiring no Memory (7)}

This trait was affected by carbamazepine consumption. Indeed, under that drug consumption, the ants were very reluctant in moving inside the presented chicanes (Figure 1C). Sometimes, they moved through one or two chicanes, then stopped during a rather long time, and then, generally turned back on their way. No ants reached the free loggia, while under normal diet six ones could do so (Table 2 , table line 1 ). This results was statistically significant: small loggia: $\mathrm{N}=5, \mathrm{~T}=15, \mathrm{P}=0.031$; free loggia: $\mathrm{N}=4, \mathrm{~T}=10, \mathrm{P}=: 0.063$ ).

\subsection{Brood Caring Behavior (8)}

This trait was not affected by carbamazepine consumption. The ants consuming that drug went on taking in their mandibles the larvae removed from the nest. They did so as usually, in a very short time period (Figure 1D). They hold the larva and moved towards the nest entrance. Comparatively with what occurred under normal diet, they only took some more time for reaching the nest entrance and re-entering the larvae. But this small decrease in rapidness was not statistically significant (Table 2, table line 2); the numbers of remaining larvae on the foraging area under the two kinds of diet did not statistically differ $(\mathrm{N}=3, \mathrm{NS})$.

At the end of the entire experimental work, the largest larvae had reached the nymphal stage (white nymphs were observed), and the smallest ones had developed up to larger ones. The ants consuming carbammazepine have thus 
taken care of their brood. During the same experimental time period, in societies under normal diet, brood development was slightly more rapid (a few pigmented nymphs were observed).

\subsection{Visual and Olfactory Perception $(9,10)$}

After having found their meat food near two visual cues for six days (Figure 1E), the ants reacted to each of these cues presented either separately or together (Table 3 ). Their mean number in front of the two cues (1.15) was lower than the sum of their mean numbers in front of each two cues $(0.90$ and 0.85$)$. The ants so reacted to, and have consequently perceived, each of the two cues. This result was statistically significant (blue cue: $\mathrm{N}=10, \mathrm{~T}=55, \mathrm{P}$ $=0.001$; yellow cue: $\mathrm{N}=7, \mathrm{~T}=28, \mathrm{P}=0.008$; blue + yellow cues: $\mathrm{N}=10, \mathrm{~T}=55, \mathrm{P}=0.001$ ). After having been trained during nine days, ants also reacted to each cues (each time: $\mathrm{N}=10, \mathrm{~T}=55, \mathrm{P}=0.001$ ), and were similarly present in front of only one cue or of the two ones (Table 3).

After having found their sugar food in the vicinity of two odors for six days, the ants reacted to these odors presented either separately or together (Table 3). Their mean number in front of the two odors was lower than the sum of their mean number in front of each odor $(0.75<0.80+1.15)$. The ants have thus perceived and memorized each of the two odors. The ants counted in presence of the odors were statistically more numerous than those counted in the absence of any odor (thyme: $\mathrm{N}=8, \mathrm{~T}=36, \mathrm{P}=0.004$; estragon: $\mathrm{N}=10, \mathrm{~T}=55, \mathrm{P}=0.001$; thyme + estragon: $\mathrm{N}=7, \mathrm{~T}=28, \mathrm{P}=0.008$ ). It must be noted that the ants' reaction to the olfactory cues was somewhat lower that their reaction to the visual cues, though the tested species essentially uses its olfaction for performing their social tasks (Cammaerts \& Rachidi, 2009). After nine days of training, the ants again reacted to the olfactory cues presented separately or together (Table 3; thyme: $\mathrm{N}=8, \mathrm{~T}=36, \mathrm{P}=0.004$; estragon or the two cues: $\mathrm{N}=10$, $\mathrm{T}=55, \mathrm{P}=0.001$ ), and were similarly numerous in front of one or the other or the two cues. Once more, the ants' olfactory reaction had a lower level than their visual one, what is not usual for them, this revealing some impact of carbamazepine consumption on their olfactory perception.

\subsection{Tactile ("pain") Perception (11)}

Ants went on having difficulties in moving on the rough bottom but they however moved on it, making unusual movements with their legs, turning their bodies, and so progressing in their trajectories, whatever they tactically perceived (Figure 1F). But they moved slowly (as under carbazepine consumption). So, even if the last numbers of counted ants in each zone obviously differed from the control ones (Table 2, table line 3), only the entire series of ants counted in the initial zone statistically differed from the control ones $(\mathrm{N}=5, \mathrm{~T}=-5, \mathrm{P}=0.031)$. As for the ants' locomotion on the rough bottom, it was far less impacted by the uncomfortable situation than under normal diet (Table 2, table line 3). Indeed, the ants' linear speed meanly equaled $7.8 \mathrm{~mm} / \mathrm{sec}$, a value statistically larger than that observed in the same situation, under normal diet $\left(3.7 \mathrm{~mm} / \mathrm{sec} ; \chi^{2}=40.62, \mathrm{df}=1, \mathrm{P}<0.001\right)$, while the ants' sinuosity meanly equaled $152 \mathrm{ang}$. deg./cm, what was statistically lower than the sinuosity observed in the same situation, under normal diet (318 ang. deg. $\left./ \mathrm{cm} ; \chi^{2}=31.45, \mathrm{df}=1, \mathrm{P}<0.001\right)$. On the rough bottom, the ants consuming carbamazepine only presented some difficulty in moving, and their linear speed was so somewhat lower than on an usual substrate $\left(7.8 \mathrm{~mm} / \mathrm{sec} v s 9.7 \mathrm{~mm} / \mathrm{sec} ; \chi^{2}=12.08, \mathrm{df}=2, \mathrm{P}<0.01\right)$, while their sinuosity was statistically similar (152 ang. deg./cm vs 177 ang. deg./cm; $\left.\cdot \chi^{2}=1.47, \mathrm{df}=2, \mathrm{NS}\right)$.

\subsection{Aggressiveness towards Congeners and Aliens $(12,13)$}

These traits were somewhat impacted by carbamazepine consumption.

During congeners encountering, the ants consuming that drug took some longer time periods for recognizing their nestmates than ants under normal diet. Therefore, they presented some aggressiveness at the beginning of such encountering. This observation was confirmed by the obtained numerical results: comparatively with what occurred under normal diet, under carbamazepine consumption less meetings with no reaction occurred while more meetings with mandibles opening (Figure $1 \mathrm{G}$ ) and some meetings with gripping behavior were recorded (Table 2 , table line 4$)$, this being statistically significant $\left(\chi^{2}=56.25, \mathrm{df}=2, \mathrm{P}<0.001\right)$.

In the same way, during aliens encountering, ants consuming carbamazepine took some longer time periods before recognizing the alien character of the encountered ants, and consequently reacted with some delay. Comparatively with normal diet situation, under carbamazepine consumption situation, more encountering with no reaction, with only antennal contacts, and with only mandibles openings occurred while less encountering with gripping behavior were recorded (Table 2 , table line 4 ). These numerical results were statistically significant $\left(\chi^{2}=21.72, \mathrm{df}=3, \mathrm{P}<\right.$ 0.001 ).

\subsection{Dependence on Carbamazepine Consumption (14)}

Meanly, for nest 1, 5.58 and 2.08 ants were counted on the food free of carbamazepine and on that containing that drug respectively (Figure 1H), while for nest 2, these mean numbers equaled 2.92 and 7.83 respectively. So, in 
total, meanly $4.25(=46.35 \%)$ ants chose food free of carbamazepine, while $4.92(=53.95 \%)$ chose that containing the drug. We thus observed, on ants, no dependence on carbamazepine consumption, this results being statistically validated (the difference between the counts on each two kinds of food was not statistically significant: $\chi^{2}=1.32$, $\mathrm{df}=1, \mathrm{NS})$.

\subsection{Habituation to Carbazepine Consumption (15)}

After two weeks of carbamazepine consumption, the ants' movement was obviously unchanged, i.e. identical to that presented after two days of that drug consumption. The ants moved slowly, stopped, turned to their left then to their right, came back on their way. The numerical results reflected this observation (Table 5). The ants' linear speed was still lower than the usual one $\left(\chi^{2}=26.67, \mathrm{df}=1, \mathrm{P}<0.001\right)$, and was similar to that assessed after two days of carbamazepine consumption $\left(\chi^{2}=1.45, \mathrm{df}=2\right.$, NS). The ants' sinuosity was still larger than the usual one $\left(\chi^{2}=24.38, \mathrm{df}=2, \mathrm{P}<0.001\right)$, and was similar to that quantified after two days of carbamazepine consumption $\left(\chi^{2}\right.$ $=0.63, \mathrm{df}=2, \mathrm{NS})$. In the same way, after two weeks of carbamazepine consumption, the ants' orientation towards an alarm signal was still as poorly efficient as after two days of that drug consumption. The ants moved either towards a wrong direction, or slowly and sinuously towards the signal but stopped, turned back or moved beyond the alarm signal. The numerical results confirmed this observation (Table 5). The ants' orientation (64.1 ang. deg.) still statistically differed from the usual one $\left(\chi^{2}=20.83, \mathrm{df}=2, \mathrm{P}<0.001\right)$, and was statistically similar to that presented after two days of carbamazepine consumption $\left(\chi^{2}=0.15, \mathrm{df}=2, \mathrm{NS}\right)$.

\subsection{Visual and Olfactory Conditioning Ability and Memory $(16,17,18,19)$}

The ants' visual conditioning ability and visual memory were obviously enhanced by carbamazepine consumption (Table 5, upper part). Comparatively with what occurred under normal diet, ants consuming carbamazépine acquired $10 \%$ more of conditioning score and kept about $10 \%$ more of their visual learning. These results were statistically significant: each time, $\mathrm{N}=6, \mathrm{~T}=21, \mathrm{P}=0.016$.

The ants' olfactory conditioning ability and memory were also largely enhanced by carbamazepine consumption (Table 5 , lower part). The ants were more quickly conditioned, and acquired $5 \%$ more of conditioning score. After removal of the olfactory cue, they went on correctly responding to the cue (Figure 1I), presenting a score of 70\%, instead of $55 \%, 72 \mathrm{hrs}$ later, having so $15 \%$ more of olfactory memory. These results were statistically significant: each time, $\mathrm{N}=6, \mathrm{~T}=21, \mathrm{P}=0.016$.

\subsection{Decrease of the Effects after Carbamazepine Consumption Ended (20)}

The effects of carbamazepine vanished, after its consumption ended, in about $20 \mathrm{hrs}, 26 \mathrm{hrs}$ or $32 \mathrm{hrs}$ according to the physiological traits assessed (linear speed, sinuosity, orientation) (Figure 2).

More precisely, the ants' linear speed initially affected by the drug $(8.8 \mathrm{~mm} / \mathrm{sec}$ instead of $14.4 \mathrm{~mm} / \mathrm{sec})$ equaled $8.6,10.2,10.9,11.3,13.9$, and finally $14.2 \mathrm{~mm} / \mathrm{sec} 2,5,8,12,18$ and $24 \mathrm{hrs}$ respectively after the ants ceased consuming the drug. Statistically, the values occurring at $\mathrm{T}=8 \mathrm{hrs}$ was still statistically different from the control ones $\left(\chi^{2}=7.57, \mathrm{df}=2, \mathrm{P} \approx 0.02\right)$, those at $12 \mathrm{hrs}$ no longer statistically differed from the control ones $\left(\chi^{2}=4.06\right.$, $\mathrm{df}$ $=2,0.10<\mathrm{P}<0.20)$, and those at $18 \mathrm{hrs}$ were still more similar to the control ones $\left(\chi^{2}=3.48, \mathrm{df}=2,0.10<\mathrm{P}<\right.$ $0.20)$. The decrease of the effect of carbamazepine on the ants' linear speed (V) was a linear function of the time $(\mathrm{T}): \mathrm{V}=8.666+0.2498 \mathrm{~T}(\mathrm{r}=977, \mathrm{P}=0.0002)$.

Concerning the ants' angular speed initially impacted by carbamazepine (196 ang. deg./cm instead of 104 ang. deg./cm), it successively equaled 182, 175, 157, 151, 121, 112 and 108 ang. deg./cm, 2, 5, 8, 12, 18, 24 and 29 hrs respectively after the end of this drug consumption. Statistically, the values obtained at $\mathrm{T}=12 \mathrm{hrs}$ still differed from the control ones $\left(\chi^{2}=18.64, \mathrm{df}=2, \mathrm{P}<0.001\right)$, those at $\mathrm{T}=18 \mathrm{hrs}$ somewhat also differed from the control ones $\left(\chi^{2}=5.57, \mathrm{df}=2, \mathrm{P} \approx 0.05\right)$, and those at $\mathrm{T}=24 \mathrm{hrs}$ were similar to the control ones $\left(\chi^{2}=1.42, \mathrm{df}=2\right.$, NS). The decrease of the effect of carbamazepine on the ants' sinuosity (S) was a linear function of the time (T): $\mathrm{S}=188.37$ $-3.112 \mathrm{~T}(\mathrm{r}=-0.979, \mathrm{P}=0.00002)$.

As for the ants' orientation towards an alarm signal, largely affected by carbamazepine consumption (69.8 ang. deg. instead of 35.8 ang. deg.), it progressively reached again its usual value equaling 61.5, 62.5, 58.0, 47.6, 43.9, 42.0, 40.5, and 32.2 ang. deg., 2, 5, 8, 12, 18, 24, 29 and $36 \mathrm{hrs}$ respectively after that the ants stopped consuming that drug. The values existing at $\mathrm{T}=12 \mathrm{hrs}$ statistically differed from the control ones $\left(\chi^{2}=7.48, \mathrm{df}=2, \mathrm{P} \approx 0.02\right)$. Those obtained at $\mathrm{T}=18 \mathrm{hrs}$ were at the limit of significance $\left(\chi^{2}=4.92, \mathrm{df}=2,0.05<\mathrm{P}<0.01\right)$. The values occurring at $\mathrm{T}=24 \mathrm{hrs}$ and $\mathrm{T}=29 \mathrm{hrs}$, though not yet identical to the control ones, were not statistically different from them $\left(24\right.$ hrs: $\chi^{2}=1.87$, df $=2$, NS; 29 hrs: $\chi^{2}=0.92$, df $=2$, NS $)$. At $\mathrm{T}=36$ hrs, the values of the ants' orientation were statistically similar to the control ones, and even slightly (but not statistically) of better quality 
(32.2 ang. deg. instead of 35.8 ang. deg.). The decrease of the effect of carbamazepine on the ants' orientation (O) towards an alarm signal was a linear function of the time $(\mathrm{T})$ : $\mathrm{O}=65.05-0.95 \mathrm{~T}(\mathrm{r}=-0.962, \mathrm{P}=0.00004)$.

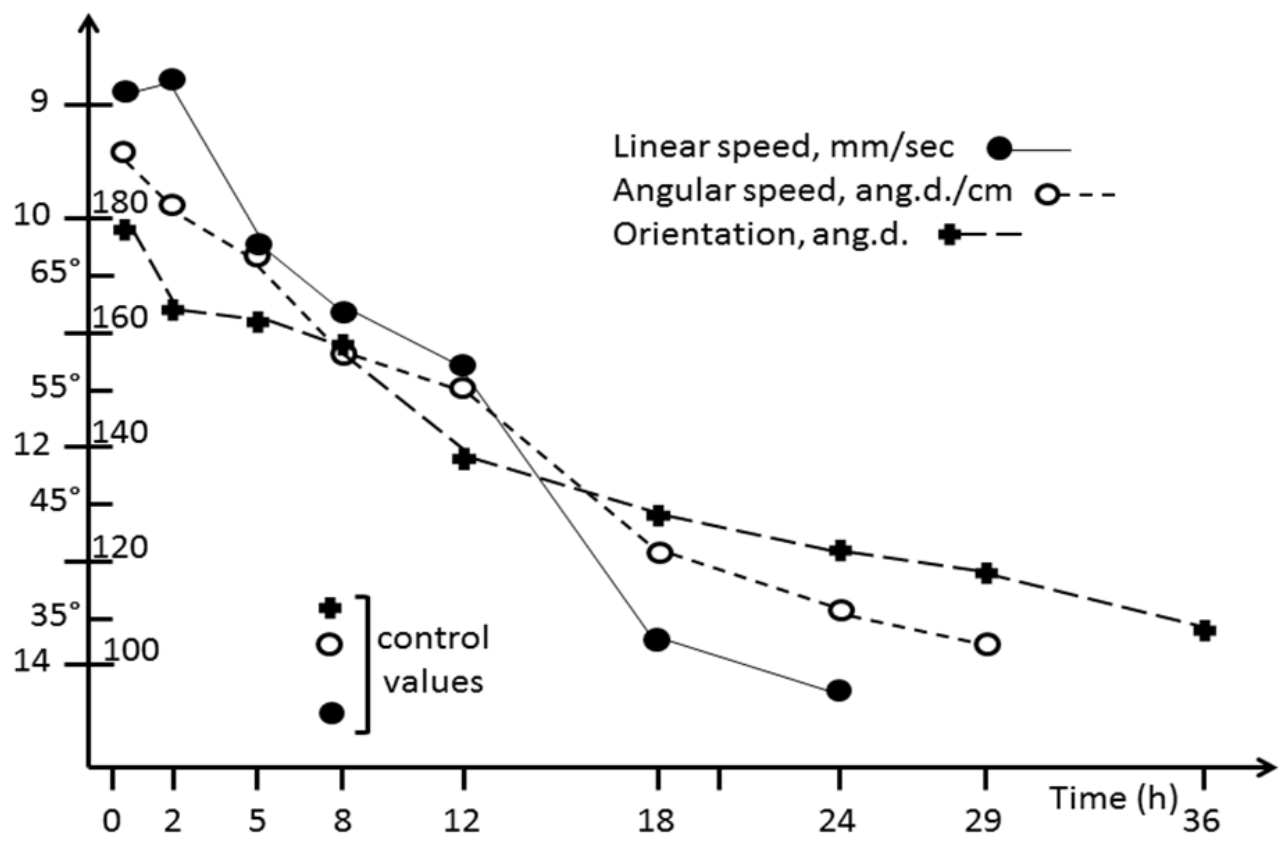

Figure 2. Decrease of the effects of carbamazepine after its consumption ends.

The effect of carbamazepine on the ants' speed of locomotion vanished in $20 \mathrm{hrs}$, that on the ants' sinuosity of movement in $26 \mathrm{hrs}$, and that on the ants' orientation towards an alarm signal in about $32 \mathrm{hrs}$. Experimental and statistical details are given in the text, in the 'Material and Methods' and the 'Results' sections respectively.

\section{Discussion}

Carbamazepine being one of the most common drug-based pollutants substances of natural water and considering the fact that this drug is acting on nervous system, it may impact the biology of many aquatic animals. So, we examined its physiological (through behavioral experiments) and ethological effects using ants as biological models. Effectively, this drug increased the ants' sinuosity of movement, decreased their speed of locomotion, the precision of their reaction, their 'audacity', their research activities for food, their cognitive ability in navigating through chicanes, and decreased slightly their olfactory perception and their tactile perception. It induced aggressiveness between congeners, slightly reduced that towards aliens, and largely increased the ability in acquiring conditioning, as well as their memory capacities. It did not impact their response to congeners' pheromones, their brood caring behavior and their visual perception. Ants never developed dependence on, or habituation to, that drug consumption. These effects vanished in $20 \mathrm{hrs}$ (linear speed), $26 \mathrm{hrs}$ (sinuosity), and 32 hrs (orientation ability) after the end of consumption of that drug.

Some of these effects are in agreement with those observed on people consuming carbamazepine: increase of sinuosity, no dependence, no habituation (see references in the Introduction section). Others might be novelty revealed, although they have been demonstrated on ants and not yet on mammals: decrease of precision of reaction, decrease of 'audacity', occurrence of some aggressiveness, decrease of tactile perception, increase of memory. As a precaution, they should be taken into account, when carbamazepine is given to people, as attention is actually paid to some observed unwanted effects: headache, nausea, photo sensitivity, trouble of heartbeat.

On the other hand, the here revealed effects of carbamazepine may occur for organisms living in natural water contaminated with that drug. These organisms may move more slowly and more sinuously, be less effective in their search for food or preys, somewhat aggress their congeners, be less incline in performing risky tasks e.g. predation behavior, have their olfaction and tactile perception somewhat reduced. These potential harmful effects of neuronal drugs on invertebrates' behaviors are worrying because they may modify the behavioral processes that 
occur in invertebrate communities of running and still waters, in which locomotion behaviors and sensitive capacities play crucial roles in structuring the food webs. Exposed to chronic contamination by this drug, aquatic invertebrates might be disadvantaged in front of predators or competitive neighbor species, and less able to compete for resources. They might thus have somewhat reduced life expectancy and reproduction rates. Carbamazepine is obviously not the only pollutant substances present in natural water. Indeed, other drugs (hormones, antibiotics, antidepressants), even if they are less common, have been identified in natural waters and are known to have strong physiological and ethological effects on invertebrates (details and references in the introduction section). We so pledge for a profound revision of classical systems of wastewater treatment. These systems should be modified and ameliorated to eliminate these unwanted substances largely used by humans and found intact in natural water, in order to better protect the aquatic fauna of our rivers and the quality of the ecological processes taking place in these rivers.

Finally, the present work, like previous ones (cited in the Introduction section) shows that ants can be used as biological models for approaching effects of substances, situations, and abnormal elements. Insects react quite similarly to humans when exposed to similar stimuli (Mylecharane, Spence, Sheumack, Claassens \& Howden, 1989); ants have a nicotinic receptor (Gauthier, 2010). Moreover, as detailed in the Introduction section, ants are easily maintained in laboratories, are evolved, eu-social, and have plenty of cognitive abilities. However, if ants can be excellent models for invertebrates, experimentation on mammals (rats, mice, monkeys; for instance) is required before stating conclusions for humans.

\section{Acknowledgements:}

We sincerely thank Dr R. Cammaerts who performed some experiments with us, supported us while we had to continuously work on ants, and made the Mann-Whitney tests for us.

\section{Conflict of interest}

We affirm having no conflict of interest while studying ethological and physiological effects of substances and drugs used by humans.

\section{References}

Abramson, C. I., Wells, H., \& Janko, B. (2007). A social insect model for the study of ethanol induced behavior: the honey bee. In R. Yoshida (Ed.), Trends in Alcohol Abuse and Alcoholism Research (pp. 197-218). Nova Sciences Publishers, Inc..

Andre, R. G., Wirtz, R. A., \& Das, Y. T. (1989). Insect Models for Biomedical Research. In A. D. Woodhead (Ed.), Nonmammalian Animal Models for Biomedical Research (November 13, 2008). Boca Raton, FL: CRC Press.

Arnold, K. E., Boxall, A. B. A., Brown, A. R., Cuthbert, R. J., Graw S., Hutchinson, T. H., Jobling, S. ... Thompson, H. M. (2013). Assessing the exposure risk and impacts of pharmaceuticals in the environment on individuals and ecosystems. Biology Letters, 9, 20130492, http://dx.doi.org/10.1098/rsbl.2013.0492

Arzul, G., Quiniou, F., Croquette, J., \& Caisey, X. (2002). Évolution saisonnière de la réponse des populations phytoplanctoniques à la présence de peintures antifouling. Meeting at Paris 9 - 12 September 2002.

Ash, R. L. J. L., \& Iverson, J. L. (2002). Antibiotic and Disinfectant Resistant Bacteria in Rivers of the United States. Emerging Infectious Diseases Journal, 8(7), 713-716. http://dx.doi.org/10.3201/eid0807.010264

Billen, J., \& Morgan, E. D. (1998). Pheromone communication in social insects - sources and secretions. In R. K. Vander Meer, M. D. Breed, K. E. Espelie, \& M. L. Winston (Eds.), Pheromone Communication in Social Insects: Ants, Wasps, Bees, and Termites (pp. 3-33). Westview Press, Boulder, Oxford.

Brodin, T., Fick, J., Jonsson, M. \& Klaminder, J. (2013). Dilute Concentrations of a Psychiatric Drug Alter Behavior of Fish from Natural Populations. Science, 339(6121), 814-815. http://dx.doi.org/10.1126/science. 1226850

Bronmark, C., \& Hansson, L. A. (2002). The biology of lakes and ponds. Biology of habitats series. New York: Oxford University Press Inc.

Cammaerts, M.-C. (2007). Colour vision in the ant Myrmica sabuleti MEINERT, 1861 (Hymenoptera: Formicidae). Myrmecological News, 10, 41-50.

Cammaerts, M.-C. (2008). Visual discrimination of cues differing as for their number of elements, their shape or their orientation, by the ant Myrmica sabuleti. Biologia, 63, 1169-1180. http://dx.doi.org/10.2478/ s11756-008-0172-2 
Cammaerts, M.-C. (2012). Navigation system of the ant Myrmica rubra (Hymenoptera, Formicidae). Myrmecological News, 16, 111-121.

Cammaerts, M.-C. (2013a). Ants' learning of nest entrance characteristics (Hymenoptera, Formicidae). Bulletin of Entomological Research, 6. http://dx.doi.org/10.1017/S0007485313000436

Cammaerts, M.-C. (2013b). Learning of trail following behaviour by young Myrmica rubra workers (Hymenoptera, Formicidae). ISRN Entomology, Article ID 792891.

Cammaerts, M.-C. (2014a). Learning of foraging area specific marking odor by ants (Hymenoptera, Formicidae). Trends in Entomology, 10, 11-19.

Cammaerts, M.-C. (2014b). Performance of the species-typical alarm response in young workers of the ant Myrmica sabuleti is induced by interactions with mature workers. Journal of Insect Sciences, 14(1), 234. http://dx.doi.org/10.1093/jisesa/ieu096

Cammaerts, M.-C. \& Cammaerts, D. (2009). Light thresholds for colour vision in the workers of the ant Myrmica sabuleti (Hymenoptera: Formicidae). Belgian Journal of Zoology, 138, 40-49.

Cammaerts, M.-C. \& Cammaerts, D. (2015a). Physiological and ethological effects of fluoxetine, a study using ants as biological models. International Journal of Biology, 7(2). http://dx.doi.org/10.5539/ijb.v7n2p1

Cammaerts, M.-C. \& Cammaerts, D. (2015b). Physiological and ethological effects of antidepressants: a study using ants as biological models. International Journal of Pharmaceutical Science Invention, 4(2), 4-24.

Cammaerts, M.-C. \& Cammaerts, R. (2014). Physiological and ethological effects of morphine and quinine, using ants as biological models. Journal of Pharmaceutical Biology, 4, 43-58.

Cammaerts, M.-C. \& Gosset, G. (2014a). Impact of age, activity and diet on the conditioning performance in the ant Myrmica ruginodis used as a biological model. International Journal of Biology, 6(2), 10-20. http://dx.doi.org/10.5539/ijb.v6n2p10

Cammaerts, M.-C. \& Gosset, G. (2014b). Ontogenesis of visual and olfactory kin recognition, in the ant Myrmmica sabuleti (Hymenoptera, Formicidae). Annales de la Société Entomologique de France, 50, 358-366.

Cammaerts, M. C., Gosset, G., \& Rachidi, Z. (2014a). Some physiological and ethological effects of nicotine; studies on the ant Myrmica sabuleti as a biological model. International Journal of Biology, 6, 64-81. http://dx.doi.org/10.5539/ijb.v6n4p64

Cammaerts, M.-C., Morel, F., Martino, F., \& Warzée, N. (2012b). An easy and cheap software-based method to assess two-dimensional trajectories parameters. Belgian Journal of Zoology, 142, 145-151.

Cammaerts, M.-C., \& Nemeghaire, S. (2012). Why do workers of Myrmica ruginodis (Hymenoptera, Formicidae) navigate by relying mainly on their vision? Bulletin de la Société Royale Belge d'Entomologie, 148, 42-52.

Cammaerts, M.-C., \& Rachidi, Z. (2009). Olfactive conditioning and use of visual and odorous elements for movement in the ant Myrmica sabuleti (Hymenoptera, Formicidae). Myrmecological news, 12, 117-127.

Cammaerts, M.-C., Rachidi, Z., \& Cammaerts, D. (2011). Collective operant conditioning and circadian rhythms in the ant Myrmica sabuleti (Hymenoptera, Formicidae). Bulletin de la Société Royale Belge d'Entomologie, $147,142-154$.

Cammaerts, M.-C., Rachidi, Z., \& Gosset, G (2014b). Physiological and ethological effects of caffeine, theophylline, cocaine and atropine; study using the ant Myrmica sabuleti (Hymenoptera, Formicidae) as a biological model. International Journal of Biology, 3, 64-84. http://dx.doi.org/10.5539/ijb.v6n3p64

Cammaerts-Tricot, M.-C. (1973). Phéromone agrégeant les ouvrières de Myrmica rubra. Journal of Insect Physiology, 19, 1299-1315. http://dx.doi.org/10.1016/0022-1910(73)90213-8

Carbamazepine. (2015). In Reseau-Pic. Retrieved from http://www.reseau-pic.info/?dest=medicaments/ carbamazepine.htm

Carbamazépine. (2015). In Wikipedia, the free encyclopedia. Retrieved from http://fr.wikipedia.org/wiki/ Carbamazépine

Corcoran, J., Winter, M. J., \& Tyler, C. R. (2010). Pharmaceuticals in the aquatic environment: A critical review of the evidence for health effects in fish. Critical Reviews in Toxicology, 40(4), 287-304. http://dx.doi.org/10.3109/10408440903373590 
Damasio, J., Barcelo, D., Brix, R., Postigo, C., Gros, M., Petrovic, M., Sabater, S. ... Barata, C. (2011). Are pharmaceuticals more harmful than other pollutants to aquatic invertebrate species: A hypothesis tested using multi-biomarker and multi-species responses in field collected and transplanted organisms. Chemosphere, 85, 1548-1554. http://dx.doi.org/10.1016/j.chemosphere.2011.07.058

Dodds, W. K. (2002). Freshwater ecology: concepts and environmental applications. San-Diego, London: Academic Press. http://dx.doi.org/10.1002/aqc.555

Gauthier, M. (2010). State of the art on the insect nicotinic acetylcholine receptor function in learning and memory. Advances in Experimental Medicine and Biology, 683, 97-117.

Giller, P. S., \& Malmqvist, B. (2002). The Biology of Streams and Rivers. New York: Oxford University Press Inc.

Ginebreda, A., Munoz, I., Lopez de Alda, M., Brix, R., Lopez-Doval, J., \& Barcelo, D. (2009). Environmental risk assessment of pharmaceuticals in rivers: Relationships between hazard indexes and aquatic macroinvertebrate diversity indexes in the Llobregat River (NE Spain). Environment International, 10 pages.

Guide des médicaments. (2015). In Doctissimo. Retrieved from http://www.doctissimo.fr/medicamentTEGRETOL.htm

Hölldobler, B., \& Wilson, E. O. (1990). The ants. Harvard University Press, Springer-Verlag Berlin, 732pp. http://dx.doi.org/10.1007/978-3-662-10306-7

Keller, L., \& Gordon, E. (2006). La vie des fourmis (p. 204). Odile Jacob, Paris.

Keller, R. A. (2011). A phylogenetic analysis of ant morphology (Hymenoptera: Formicidae) with special reference to the Poneromorph subfamilies. Bulletin of the American Museum of Natural History, 355, 99pp. $\mathrm{http}: / / \mathrm{dx}$.doi.org/10.1206/355.1

Klaper R. (2013). Les poissons vivant dans des eaux contaminées par des antidépresseurs deviennent anxieux, anti-sociaux et peuvent développer des tendances meurtrières, confirme une étude réalisée par des chercheurs de l'université de Milwaukee-Wisconsin (USA). Retrieved from http://egora12.rssing.com/chan-15648280/ all_p1.html

Knoery, J. (2010). Synthèse des impacts des substances dangereuses sur l'écosystème /SRM MMN. PI_synthèse_impact_substances_dangereuses_V2_MMN. 8 pp.

Kolb, B. \& Whishaw, I.Q. (2002). Neuroscience \& cognition: cerveau et comportement. Eds Worth Publishers, New York, Basing Stoke, 635pp.

Kolpin, D., Furlong, E., Meyer, M., Thurman, E. M., Zaugg, S., Barber, L., \& Buxton, H. (2002). Pharmaceuticals, Hormones, and Other Organic Wastewater Contaminants in U.S. Streams, 1999-2000: A National Reconnaissance. USGS Staff -- Published Research. Paper 68. Retrieved from http://digitalcommons. unl.edu/usgsstaffpub/68

Kümmerer, K. (2009). Antibiotics in the aquatic environment - A review - Part II. Chemosphere, 75, 435-441. http://dx.doi.org/10.1016/j.chemosphere.2008.12.006

Lecomte, E. (2014). 7 choses à savoir sur la présence de médicaments dans l'eau. Retrieved from http://www.sciencesetavenir.fr/nature-environnement/20140829.OBS7600/7-choses-a-savoir-sur-la-presenc ede-medicaments-dans-1-eau.html

Mylecharane, E. J., Spence, I., Sheumack, D. D., Claassens, R., \& Howden, M. E. H. (1989). Action of rubostoxin, a neurotoxic polypeptide from the venom of the male funnel-web spider (Atrax rubustus), in anaesthetized monkeys. Toxicon, 27, 481-492. http://dx.doi.org/10.1016/0041-0101(89)90211-0

Olsson, P. E., Borg, B., Brunström, B., Häkansson, H., \& Klasson-Wehler, E. (1998). Endocrine disrupting substances. - Impairment of reproduction and development. Ed Elandes Gotab, Stockholm, Sweden, 148 pp.

Passera, L. (2006). La véritable histoire des fourmis. Librairie Fayard, pp 340.

Passera, L., \& Aron, S. (2005). Les fourmis: comportement, organisation sociale et évolution. Les Presses Scientifiques du CNRC, Ottawa, Canada, 480 pp.

Perturbateur endocrinien. (2015). In Wikipedia, the free encyclopedia. Retrieved from http://fr.wikipedia.org/ wiki/Perturbateur_endocrinien

Petrovic, M., Ginebreda, A., Munoz, J., \& Barcelo, D. (2013). The river drugstore: the threats of emerging pollutants to river conservation. Chap. 5 in River Conservation. Challenges and Opportunities. Fundacion BBVA. 127 pp. 
Preston, M. R. (2002). Endocrin-disrupting chemicals in marine environment. Chap. 13 in Chemistry of Marine Water and Sediments. Eds A. Glanguzza et al., Springer-Verlag, Berlin Heidelberg.

Rachidi, Z., Cammaerts, M.-C., \& Debeir, O. (2008). Morphometric study of the eye of three species of Myrmica (Formicidae). Belgian Journal of Entomology, 10, 81-91.

Ramirez-Castillo, F. Y., Harel, J., Moreno-Flores, A. C., Loera-Muro, A., Guerrero-Barrerai, A. L., \& Avelar-Gonzalez, F. J. (2014). Antimicrobial resistance: the role of aquatic environments. International Journal of Current Research and Academic Review, 2(7), 231-246.

Rilovl, G., Gasith, A., Evans, S. M., \& Benayahu, Y. (2000). Unregulated use of TBT-based antifouling paints in Israel (eastern Mediterranean): high contamination and imposex levels in two species of marine gastropods. Marine Ecology Progress Serie, 192, 229-238. http://dx.doi.org/10.3354/meps192229

Risques environnementaux et sanitaires des résidus de médicaments sur les milieux aquatiques. (2015). In Wikipedia, the free encyclopedia. Retrieved from http: //fr.wikipedia.org/wiki/Risques\%20 environnementaux $\% 20$ et $\% 20$ sanitaires $\% 20$ des $\% 20 \mathrm{r} \% \mathrm{C} 3 \%$ A 9 sidus $\% 20 \mathrm{de} \% 20 \mathrm{~m} \% \mathrm{C} 3 \%$ A9dicaments\%20sur\%20les\%20milieux\%20aquatiques?oldid=108024125

Rosi-Marshall, E. J., \& Royer, T. V. (2012). Pharmaceutical compounds and ecosystem function: an emerging research challenge for aquatic ecologists. Ecosystems. http://dx.doi.org/10.1007/s10021-012-9553-z

Russell, W. M. S., \& Burch, R. L. (2014). The Principles of Humane Experimental Technique. Johns Hopkins University.

Sauvé, S. (2011). Poissons sous antidépresseurs. Retrieved from http://www.quebecscience.qc.ca/actualites/ Poissons-sous-antidepresseurs

Siegel, S., \& Castellan, N. J. (1989). Nonparametric statistics for the behavioural sciences. Singapore: McGraw-Hill Book Company.

Søvik, E., \& Barron, A. B. (2013). Invertebrate models in addiction research. Brain Behavior and Evolution, 82, 153-165. http://dx.doi.org/10.1159/000355506

Sutcliffe, D. W. (1994). Water quality and stress indicators in marine and freshwater ecosystems: linking levels of organization (individuals, populations, communities). Published by the Freshwater Biological Association. Napier University, Edinburgh. 62 pp.

Tachet, H., Richoux, P., Bournaud, M., \& Usseglio-Polatera, P. (2010). Invertébrés d'eau douce. Systématique, biologie, écologie. CNRS Editions. 607 pp.

Wehner, R., \& Gehring, W. (1999). Biologie et physiologie animales. Bruxelles: Eds. De Boek Université, Thieme Verlag, Paris.

Wolf, F. W., \& Heberlein, U. (2003). Invertebrate models of drug abuse. Journal of Neurobiology, 54, 161-178. http://dx.doi.org/10.1002/neu.10166

Young, H. K. (1993). Antimicrobial resistance spread in aquatic environments. Journal of Antimicrobial Chemotherapy, 31(5), 627-635. http://dx.doi.org/10.1093/jac/31.5.627

\section{Copyrights}

Copyright for this article is retained by the author(s), with first publication rights granted to the journal.

This is an open-access article distributed under the terms and conditions of the Creative Commons Attribution license (http://creativecommons.org/licenses/by/3.0/). 